Article

\title{
Building London's Food Democracy: Assessing the Contributions of Urban Agriculture to Local Food Decision-Making
}

\author{
Alban Hasson \\ The Bartlett Development Planning Unit, University College London, London, WC1H 9EZ, UK; E-Mail: a.hasson.18@ucl.ac.uk \\ Submitted: 13 March 2019 | Accepted: 1 September 2019 | Published: 28 October 2019

\begin{abstract}
This article presents the contributions of Urban Agriculture practitioners in establishing the local food movement and the foundations of an active food democracy in London. It argues that food democracy is emerging from a set of contestations within institutional channels, but also through the historical struggle of formulating the dominating political discourses, both of which are co-constituted through specific social and political practices. Webster and Engberg-Pedersen's political space framework (2002) breaks up this article in order to describe: 1) How specific institutional channels form different strategies of collaboration and contestation; 2 ) how these are reflected in political discourses evolution; and 3) what dilemmas and opportunities this evolution in practice entails in relation to responsibilisation and its influence on the possibility of establishing true active food democracy in London.
\end{abstract}

\section{Keywords}

allotments; community food projects; food democracy; political space; responsibilisation; urban agriculture

\section{Issue}

This article is part of the issue "New Perspectives on Food Democracy" edited by Basil Bornemann (University of Basel, Switzerland) and Sabine Weiland (Université Catholique de Lille, France).

(C) 2019 by the author; licensee Cogitatio (Lisbon, Portugal). This article is licensed under a Creative Commons Attribution 4.0 International License (CC BY).

\section{Introduction}

The 'food democracy' concept was first coined by Lang (1998) and later expanded by Hassanein (2003) to argue that in their everyday lives people can and should be more actively participating in shaping the food system. This concern towards popular control over food policy is not a new phenomenon and has existed throughout the history of food-related social movements. The resurfacing of the food democracy concern in the late 1990s, however, became characterised by the opposition to a neo-liberal vision in which the market monopolises power with retailers acting as gatekeepers between supply and consumption, and an older welfarist and socialist perspective arguing that food systems should not be abandoned to the market but rather governed by more active political deliberations (Lang, 1998, p. 18). This democratic deficit in our food systems has been explored through other concepts such as food citizenship (Renting, Schermer, \& Rossi, 2012) and food sovereignty
(Pimbert, 2009), both arguing that the current food regime is too centralised, perceiving food only as a commodity and only acting through liberal economic rhetoric (McMichael, 2008, pp. 212-213; Pimbert, 2009).

In light of this, urban agriculture (UA), defined as 'the growing, processing, and distribution of food and other products through intensive plant cultivation and animal husbandry in and around cities' (Bailkey \& Nasr, as cited in Monardo, 2013, p. 3), appears as a valuable practice because of its contribution to establishing a local food movement for cities, a closeness that enables the formation of an urban form of food democracy. London has one of the largest networks and highest percentage of UA amongst richer nations, but also established some forms of food democracy through different institutional channels. For these reasons, it makes a very interesting case study to assess the influence of UA networks on promoting further urban food democracy. Still, it should be kept in mind that such configuration is far from the norm in the UK and beyond. 
Due to the heterogenous nature of on-the-ground realities behind the promotion of further food democracy in London, this article suggests that a layered framework of political space could help explain the complex and mutually constitutive mechanisms between institutional channels, and their specific political discourses and social/political practices. Overall, this analysis should contribute to precising the knowledge of how UA practitioners contest political space in order to set up a local food movement and the foundations of an active food democracy. And critically, it questions whether an active food democracy entails a pragmatist individual-focus direction for the local food movement, a direction which is not suited to addressing systemic issues in a more radical manner because of its non-political nature (Crawford, 1980; Noll, 2014).

After presenting our methodology (Section 2), this article will focus on institutional channels as spaces that allow and shape different strategies of participation and contestation for food democracy by UA practitioners (Section 3). Then, it will present some of the main political discourses which historically articulated different conceptions of UA to contextualise the evolution of the struggle for this second dimension of political space. It shall also discuss the latest shift of the local food movement towards neo-liberal governmentality, its implications for UA and what impacts this has on institutional channels and social and political practices (Section 4). The last part will explore the dilemmas and opportunities behind this change in practices following the evolution of channels and discourses, especially the debates between mainstreaming or losing transformative potential, the opportunities offered by State withdrawal and responsibilisation approaches versus system-based directions (Section 5).

\section{Conceptual Framework and Methodology}

Food democracy is about citizens conquering political space to have the power to determine agro-food policies and practices at all scales. Our analysis of UA in London uses the framework of political space as presented by Neil Webster and Lars Engberg-Pedersen (2002). In this work, the authors use this categorisation to highlight the layers on which the urban poor contest political space for poverty reduction. It will be used to look at how the UA practitioner contests political space for UA facilitation. Following this framework, it is argued, will provide a good structure to understand the complexities of the contributions of UA to the local food movement and to the establishment of an active food democracy in London.

Pringle and Watson (as cited in Webster \& EngbergPedersen, 2002) remind us that interests:

Are constructed in the process of interaction with specific institutions and sites. The policies that ensues depend not just on the constraints of structures, but on the discursive struggles which define and constitute particular interests and the State at one time. (p. 81)

The idea of space and boundaries helps picture this discursive struggle and is necessary to understand what constrained and enabled approaches towards the advancement of UA, the local food movement and food democracy. This framework enables us to grasp the power relations that help to shape the boundaries of these spaces, what is possible within them, and who may enter, with which identities, discourses and interests.

Hence, this research was organised to follow the three mutually constitutive layers of political spaces:

- Institutional channels that include formal procedures for affecting food policy formulation and implementation such as elections, general assemblies, coordination meetings or hearing procedures and which can be shaped by particular political discourses and practices;

- Political discourses that encompass the ideas central to the formation of popular culture about food such as rights, responsibilities and culpability and which build different approaches towards policy relating to specific institutional channels and political practices;

- Social and political practices, i.e., the specific ways, tactics and strategies of different social groups to attempt to exercise influence on food policy-making, these constitute a collective memory of what has been achieved and how, in relation to new political discourses or institutional constraints.

Concretely, this means the first step to accurately describe UA practitioners' engagement in London's local food policy should start with an analysis of the institutional channels available and to interrogate how these privilege certain priorities, actors and interventions. Looking at power imbalances within these channels and how they contribute to shaping collaborations, legitimacies and representativeness of actors is fundamental. Doing this necessitates a comparative analysis of the two main strategies of UA practitioners shaped by these specific institutional channels, namely contestation and/or collaboration. Information for this part was collected through grounded theory (Charmaz, 2006; Strauss \& Juliet, 1994) and content analysis (Krippendorff, 2004) of secondary data and literature, including journal articles, specialised reports and censuses, organisation and governmental websites relating to London's UA between 1996 and 2018. Looking at the specific examples of the London Food Strategy and the London Plan of 2018, but also the London Food Board and the Capital Growth campaign gives this article a good overview of the successes and failures of the different interventions happening within the institutional channels available for food democracy in London. 
The next step is to describe and analyse elements of this discursive struggle between institutional channels, discourses and practices and this starts with an historical depiction of the main political discourses that articulated the practice of UA in London. Once this contextual background is described through a narrative analysis, it would be possible to reflect on the current situation and assess whether the strategies exposed in the first part relate to specific trends of UA in London, trends which may break away from a certain narrative or instead be more of a continuation of what had previously been done. Once these depictions of institutional and sense-giving mechanisms (discourses) are completed, an accurate understanding of the latest narrative in the practice of UA in London and how it contributes to the local food policy discourse becomes possible.

Only then can this article begin to describe the main debates that agitate UA's interventions in local food policy, as it starts to capture how these interventions are not unidirectional but rather a complex web of multilevel entanglements of actors, channels, discourses, and practices. And because discourses and practices depend hugely on our conception of what exists, the two parts focusing on these would require a more epistemological relativism for observation, hence information here was collected between 2017 and 2019 through some participant observation in London's urban farms (including Calthorpe Project, Spa Hill Allotments, Hackney's Back Garden and Growing Kitchen) and some informal discussions with more than 30 urban farmers, community food activists, researchers specialised in the field and municipal rapporteurs. This was also enriched with grounded theory, content and Foucauldian discourse analysis (Foucault, 1969/2002; Keller, 2011) of organisation websites, reports, and relevant literature dating all the way to the UK's first allotment movement in 1793.

The key finding that ensues raises important questions about the different directions of the local food movement and food democracy in London, and how UA currently evolves within these various possibilities.

\section{Institutional Channels Related to UA}

One of the first examples of an institutional channel for food democracy in London was the London Food Commission run by Tim Lang under the Greater London Council in the 1980s. Nowadays it is the current Food Strategy-2018-and its predecessor-2006-which act as a Food Charter and govern most food related issues in London. These were informed by the Curry Report-2002-and the need to develop regional food strategies in England which at first was led by the regional Department for Environment, Food and Rural Affairs offices. Initially, the South East regional strategy was intended to cover London, but this was deemed impractical, so London developed its own. This London Food Strategy, the London Plan-and to a lesser extent London's Environment Strategy-, London's Health
Inequalities Strategy, advocacy work towards the councils, and chairing in the London Food Board can be said to be the main 'Institutional channels through which [food] policy formulation and implementation can be accessed, controlled or contested' (Webster \& Engberg-Pedersen, 2002 , p. 8) by ordinary citizens.

These current institutional channels seem to allow for two broad strategies that can be combined: direct contestation by community groups during the public consultation on these strategies, and/or implication in the governing institutions implementing these strategies. This part shall briefly look at these two approaches with the help of specific examples and assess their influence on UA promotion and the advancement of food democracy in London.

\subsection{Contestation in the Public Consultations}

In 2018, a draft of the strategy was submitted for consultation during an eight-week period, these included polling, online surveys, discussion forums and focus groups (Greater London Authority [GLA], 2006, 2018a). A wide range of people responded to this consultation, and responses were split into two main groups: the public and stakeholders, both comprising of UA practitioners (150 stakeholders and thousands of members of the public responded). Here 'stakeholders' means the people that are responding on behalf of an organisation such as charities and NGOs, businesses, membership organisations, professional bodies, local authorities, advertising companies, and healthcare providers or the few individuals with a specific expertise in food (GLA, 2018b, p. 9).

After the consultation, a Post-Adoption Statement (GLA, 2018c) ensures no significant adverse effects are likely especially concerning potential environmental, economic or social impacts. This post-adoption statement is also concerned with Health Impact Assessments because there is a legal (EU) commitment to doing this. Additionally, the Consultation Report (GLA, 2018b) ensures there is no major areas that stakeholders and the public are opposed to in the draft of the strategy. In 2018, the report argued that the changes made to the final LFS are mostly minor and strengthen the strategy further rather than changing its content or structure significantly' (GLA, 2018c, p. 13). This statement seems to indicate an alignment of public, stakeholder and governance opinions concerning the direction of London's food systems for the next 10 years. Considering this, it seems that mechanisms of popular control on policy formulation are ensuring some minimum level of food democracy.

Planning being one of the few powers that the Mayor and GLA possess to influence the establishment of the local food movement, looking at public consultation on the London Plan also appears to be particularly relevant. Indeed, this authority over planning has major implications for UA and should be mentioned when addressing the case of London's main institutional channels for food democracy. Interestingly, and because of these pub- 
lic consultations, instances like the London Food Strategy and the London Plan become arenas of political struggle or spaces of governance between actors, where the myriad of stakeholders previously described will come to defend their particular interests and voice their concerns. In this arena, forming alliances between various community groups and campaigners, with similar contestations, can be an effective strategy for stakeholders to make themselves more visible, in order to enable their vision to compete with the dominant actors in the debate (e.g., supermarkets, big landowners, etc.).

One good example of this, but which also demonstrates the difficulty in getting UA practitioners' voice heard is the cooperation between Just Space and the Community Food Growers Network (CFGN). Just Space is 'an informal alliance of around 80 community groups, campaigns and concerned independent organisations which was formed to act as a voice for Londoners at grass-roots level during the formulation of London's major planning strategy, particularly the London Plan' (Just Space, n.d.). It has participated in all London Plan examinations in public since 2007 and produced a communityled plan for London in which the CFGN drafted the section on Community Food Growing and Production (Just Space, 2018; Levidow, 2018, p. 370). Groups like Just Space most often draw their political strength and their ability to intervene in the public debate from the direct needs of local community organisations. But we should be wary of how some organisations cease in terms of social participation to be representative of the people they represent. Because of this issue of mainstreaming under umbrella organisations, direct participation of the communities involved could be preferred-we shall come back to the issue of mainstreaming later. Some aspects of Just Space proposals have been incorporated into the London Plan as a result of this participation. It appears however that inspectors have been variable in their willingness to admit community-based evidence (Just Space, 2018) which is not uncommon but, in this case, may be explained by the issues of community representativeness exposed before, or simply by the quality of the evidences provided. It is also argued that:

While the Mayor has consulted informally with business groups and developers, who together with a range of institutional stakeholders have had an early role in shaping the Mayor's strategic priorities and direction, there has been no attempt to ensure the early participation of community groups. (Just Space, 2018)

This temporal difference in involvement seems to indicate a power imbalance between private and civil society stakeholders, and for this reason, Just Space wants to be effectively involved in the creation of the next London Plan, not just 'consulted' on a draft plan produced in detail in semi-secret (Just Space, 2018). Accordingly, and similarly to the observations made by Bassarab, Clark, Santo, and Palmer (2019) in the US, it seems that only when there will be this guarantee of equity at all stages of decision-making can real democracy begin to be activated in London.

\subsection{Collaboration or Co-optation with Governing Institutions}

To have an earlier say in the formulation and implementation process, organisations such as Sustain (the alliance for better food and farming) used a less conflicting strategy of collaboration with governing institutions, what some might critically call co-optation. Sustain's strategy led to the Capital Growth campaign, London's largest food growing network launched for 2012 Olympic games and which is now overseeing most of UA in London.

The impact of this campaign, and ultimately that of Sustain's strategy, is difficult to measure. It is known that between 2006 and 2012 there was a net loss of 14 allotment sites (London Assembly Environment Committee, 2006; Southgate, 2012, p. 6). Allotments are traditional urban farms in the UK managed by boroughs and protected by specific legislation since 1908, which distinguishes them from other food growing projects. This result could indicate that neither the 2006 Food strategy nor the Capital Growth campaign was helpful in preserving allotments. According to 2012 last allotment census for London, there were 1758 registered Capital Growth spaces and 65 Federation of City Farms and Community Gardens (FCFCG) member spaces across London which gives a grand total, including statutory allotments, of 2534 food growing spaces in Greater London (Southgate, 2012 , p. 8). But it is necessary to precise that Capital Growth and FCFCG gardens are different to allotments in size, purpose and legal status and should not be seen as replacements for allotments (Southgate, 2012, p. 8).

After 2012, the only available reports on UA in London are the Capital Growth reports which report over 2200 members in their network in 2014 (Sustain, 2014) and 2415 gardens in 2018 (Sustain, 2019a). These numbers seem to indicate that Capital Growth has indeed developed new growing spaces, which is why the campaign is depicted as a success on the Mayor's website, but having no information on non-members of the network, on the length of these projects, or on the size of the growing spaces available it can't really be affirmed that the overall number of growing spaces has risen. This led Chang (2013) to affirm that:

While Capital Growth as a coordinator of a large number of food-growing projects also played an important role in facilitating discussions about and activities in the re-localisation of London food systems, there was no serious increase of food production from its programme. (p. 103)

Another strategy of collaboration with mainstream institutions is representation within the London Food Board, this is the equivalent of a Food Policy Council as it 
puts the Mayor's Food Strategy into practice, by coordinating work and leading debate (GLA, 2006, 2018a). According to Hassanein (2003) or Sieveking (2019), Food Policy Councils offer a concrete example of a deliberate attempt to develop the practice of food democracy, but despite the Mayor of London's aspiration to create a new food system for the city, it lacks power and resources to fulfil such an ambition (Morgan \& Sonnino, 2010). Moreover, this relatively mainstreamed nature of London's food policy is juxtaposed by the complexity of the city's local governance structure, consisting of 32 boroughs and the City of London. These borough councils are responsible for running most local services in their areas, and thus there can be significant variation in food policy priorities and implementation (Coulson \& Sonnino, 2019, p. 177). Anyhow, the Food Board's membership was partly renewed in March 2017 and this allowed for several community food activists to be appointed by the Mayor among them an activist of the CFGN as well as two representatives from Sustain (Levidow, 2018, p. 371). As a result of this participation by community food activists:

The Board advocated long-term secure tenancies for more food-growing, as...basis for infrastructural investment and organisational commitments in such spaces...[and] advocated such policies within London's strategies for environment, health and business-more important because these have a statutory basis. (Levidow, 2018, p. 371)

Despite this proposition, there was no change made to the Mayor's previous policies and the draft London Plan (responsible for planning urban spaces) made no commitment to secure food-growing spaces, although it mentioned aquaponics and vertical growing which are more relevant to commercial agriculture rather than community gardening (GLA as cited in Levidow, 2018, p. 372). This absence of a GLA response around their rationale for not including any of the proposed policy changes is problematic when assessing the level of democratisation. It also indicates that even a quasi-insider role within the GLA cannot effectively complement public interventions by the Just Space network in order to facilitate UA, advance its role in the local food movement and set up some aspects of food democracy.

Considering all this, it seems that although the democratic channels such as representation within the institutions or public consultations exist, the policymaking process is still centralised. Indeed, despite interesting collaboration strategies along these channels, civil society seems to not own the first or final say, and therefore remain confined to a consultative/implementing role rather than policy-formulating one. This choice of strategies between contesting the mainstream or trying to change it from within is mutually shaping and shaped by specific institutional channels but also relates to the two other political spaces as we shall continue to observe.

\section{Political Discourses Related to UA}

Having discussed some of the institutional channels allowing contestation/collaboration for UA in London, we now turn towards the second dimension of political space: political discourses. In London, the political discourses, concerns and motivations relating to UA have been numerous throughout the city's long history of food related social movements, some of these discourses are less central today than they used to be, but a brief overview is still important to understand the specificities of the London context, its chronology, and the recent changes that occurred.

\subsection{Overview of Political Discourses Relating to London's UA}

Historically, the practice of UA has been linked to claims about the right to land ownership or rights to food by the labouring poor: this has famously been exemplified in London and the UK through the Peasant's Revolt of 1380 and the Diggers movement of 1649 for example (opposed the enclosure of common land), which have been important events that lead to the creation of the allotment movement (Biel \& Cabannes, 2009, p. 2; Howkins, 2002; Richardson \& Ridden, 1988). This contestation for the right to cultivate land and the commons, involving the urban poor, the landowners, the State and other actors still is an important element of the political discourse surrounding UA today, as it was seen with the example of Just Space campaigns on the London Plan.

Another important element of the political discourse in UA is the relevance of this practice to the issue of securing national food supplies. Indeed, the first allotment movement is linked to shortages due to the Napoleonic wars in 1793 (Burchardt, 2002, p. 10), and the victory gardens and the Dig for Victory campaign during the two world wars are probably the most well-known examples of this phenomenon (Gibbs, 2013). Today, modern debates on national food security, particularly relevant in the context of Brexit (London Food Link \& Sustain, 2018; O'Caroll, 2018), discussions surrounding the role of the nation in guaranteeing food sovereignty (Edelman et al., 2014; Schiavoni, 2015), or even interrogations on food democracy from the top-down in this issue (Baldy \& Kruse, 2019), are examples of this constant reference to the national scale in local food system transformations. A recent example of this is Sustain's contribution to the Right to Food campaign which seeks to instate into UK law the UN Sustainable Development Goal of ending hunger which would require action both at national and local level (London Food Link \& Sustain, 2018).

After WW2 and its successful national campaign for UA, subsequent years saw a decline in use, but in 1974 Friends of the Earth's report called 'Losing Ground' initiated a brief comeback of UA concerns in the 1970s, a period called 'Allotment Frenzy' and that Leapman in his 1976 book One Man and His Plot associated with 'the dis- 
covery of the allotment by the middle class' (Crouch \& Ward, 2003, p. 165). This issue of class and who participates to UA is also of importance in London. As Engel's law demonstrates, the poorer you are, the higher proportion of your income would be spent on food: This also suggests that issues of food democracy would especially be important for the lower classes (Zimmerman, 1932). Historically, UA has been part of coping strategies for the urban poor, and for example in London today a low-income family can save up to $£ 1040$ a year with these kind of growing activities (Neighbourhoods Green, 2014 , p. 11). However, low income families are now less involved in UA as they are increasingly time poor, and for this reason it should be questioned who actually commits to UA. For example, only $50 \%$ of respondents of the capital growth said their motivations for participating to UA was to save money (Sustain, 2014). Hence, the relationship between UA and gentrification has also been questioned in recent times (Horst, McClintock, \& Hoey, 2017).

This brief surge of UA in the 1970s also led to an increase in social integration of immigrant communities, who increasingly saw UA has a way to preserve and practice their traditional farming knowledges (Monardo, 2013). This strengthened and expanded the social benefits linked to UA such as community cohesion which had been present since the first allotment movement. This continued to this day and in 2013 Sustain's members main motivations (in order of preferences) were community building, health and wellbeing, followed by learning new skills or helping others to do so, changing the food system, reducing its impact on the environment, saving money and growing food to sell (Sustain, 2014)

As mentioned, the health discourse is important for UA practitioners, but an even more dominating concern in London's governance since the 1970s, partially because the Mayor has oversight on Public Health strategies for London and that the State is constantly looking at ways to reduce the National Health Service budget. Importantly, this relates to the debate around 'Healthism' and of one's individual responsibility to health which tends to ignore social determinants and led Crawford to argue that as long as such approach 'shapes popular beliefs, we will continue to have a nonpolitical, and therefore, ultimately ineffective conception and strategy of health promotion' (Crawford, 1980, p. 365). This link to responsibilisation seems to have been the overall trend in UA in London since the mid-2000s, and that is what this article will turn to now.

\subsection{Change in Discourse: A Shift in Responsibility}

Since the international food price spikes of 2008, the Growing Food for London conference, and the new approach of Sustain with its Capital Growth campaign, allotments which constituted the bulk of the State involvement in the local food movement seem to have been progressively side-lined in London. This was witnessed by an interview partner from an academic context who partici- pated to this conference at the time and was also part of the Camden Healthy and Sustainable Food strategy. He remembers to have 'felt very strongly at the time that allotments were being totally written out of history, and this remains a very significant critique of Sustain' (personal correspondence, Biel, May 20, 2019).

Others might argue that rather than being side-lined, the allotments may have benefitted by the increased interest in UA since mid-2000s, which may be exemplified by Islington opening its first allotment in 100 years back in 2008 for example (Edwards \& Phillips, 2010). But there is evidence across the UK that allotments are being sold off for development despite government pledges to preserve them. For example, in 1996 there were four people waiting for every 100 plots, but that has risen to 57 in 2014, and about 3000 plots, $2 \%$ of the national total, have been destroyed between 2010 and 2014 according to official figures (Holehouse \& Graham, 2014). Further evidence demonstrates that the majority of food growing projects created through the Capital Growth Campaign are community food projects rather than allotments (in 2018 only $12 \%$ of Capital Growth members are allotments; Sustain, 2019a). This may be explained by the fact that the allotments waiting list are mostly full, some with 10 years waiting lists, and that no space is currently available to create new allotments, at least in Inner London boroughs where is situated most of the demand.

However, and despite this apparent side-lining of allotments, positive changes were made in the institutional channels to one of facilitation for urban food growing (e.g., neighbourhood planning, local green spaces denomination, changes in zoning ordinances). Additionally, many campaigns such as Capital Growth, or Zero Hunger City, guidance on best practices and funding opportunities such as the Big Lottery's Local Food Fund have opened the way to a range of unconventional growing projects in unconventional spaces, including council estate projects (personal correspondence, Biel, May 20, 2019; Sustain, 2019b).

Under those circumstances, this shift in discourse to community food projects may at first glance appear positive as it enables smaller growing spaces to emerge in this very constrained area. Nonetheless, this phenomenon also represents a shift of responsibility for UA provision, a responsibility that is now placed upon the individual, the private sector and civil society instead of the State. This transferal (or downscaling) of State responsibility to (under-funded and under-resourced) multi-sector food partnerships may amount to 'responsibility without power' under the guise of 'food democracy' (Peck \& Tickell, as cited in Coulson \& Sonnino, 2019, p. 171). Indeed, rather than being evidence of a democratic redistribution of roles within urban food policy, it seems these new food partnerships are instead resulting from neo-liberal austerity measures and reduced local authority budgets, among which cutbacks in public health budgets that had traditionally funded many smallscale citizen type projects. 
New practices of public-private partnerships based on civil society not for profit models and even aquaculture and micro-growing are of course interesting projects, but they have not proven to be as resilient as allotments (personal correspondence, Biel, May 20, 2019). This is mostly because they seem to be too financially dependent and legally precarious, but also too fragmented to resist to the pressure imposed by property developers, with Local Green Space denomination offering less protection than allotment status for example.

Still, the recent commercial model emerging from this shift is interesting because a true local food movement and food democracy would extend to involvement in the market. Today, microfarms could be economically viable in London with specific strategies as presented by Chang and Morel (2018) but one of the main obstacles to this is the short-term and precarious leases of the rented plots, a problem which could possibly be solved by returning to the special status of allotment. Under these circumstances, this shift in the socio-technical structure from allotments to community food projects which can be identified in institutional channels, a new discourse of responsibility, and new practices seems to be detrimental to the re-localisation of food production and to the establishment of local food democracy.

\section{Social and Political Practices Related to UA}

After having presented institutional channels and their specific contestation/collaboration strategies and explaining how these relates to an evolution of political discourses and ideological movements structuring urban food democracy in London, this article now debates the dilemmas and opportunities behind these specific social and political practices. These seem to be the main concern in today's literature on the future of the local food movement in London. We shall look at the collaborative approach of mainstreaming, the implications of State withdrawal and the shift to responsibilisation.

\subsection{Mainstreaming and Transformative Potential}

As presented in the previous parts, new forms of UA and food re-localisation:

Have achieved a tremendous 'reach,' extending to many established institutions such as schools, housing associations, community associations, public health bodies and councils, all of whom have, in countless cases, literally bought in to community food projects as a means of delivering multiple requirements. (Reclaim the Fields, n.d.)

This process of mainstreaming with common institutions, however, what we may also refer to as 'anchoring' can unfortunately dilute the transformative potential of certain social innovation oriented towards food democracy (Chiffoleau \& Loconto, 2017, p. 315).
The multi-scalar complexity of sustaining food partnerships 'creates a situation where roles, responsibilities and expectations from partners are unclear and continually negotiated, leading to a tendency to work towards consensus politics, rather than embedding notions of dissent and antagonism into these spaces' (Coulson \& Sonnino, 2019, p. 176). This tendency implies that the existing structural power relations at both the local and national level remain unchallenged. Some argue that to challenge power relations, and to not be reduced to innovation within niches, new food initiatives should not be striving for this antagonism and radical regime replacement. Instead, networking and institutionalising alternatives within the existing structures remains their best option to achieve transformative change in the dominant socio-technical regime (Levidow, 2018).

Again, Sustain's work is well suited to exemplify this tension with mainstreaming, as they can be seen as both poacher and gamekeeper, both a critical voice but also now embedded in the system delivering many services. In 2008, they organised the Growing Food for London conference which played a significant role in launching some of the ideas which were taken up opportunistically by Boris Johnson (such as Capital Growth) and they have also more recently collaborated with Michael Gove (Secretary of State for Environment, Food and Rural Affairs). These collaborations impacted their reputation as a critical voice. But still, UA practitioners who are putting forward a counter-systemic argument at a high standard will hopefully see some of their ideas filtering into public policy, although there are risks of co-optation, and risks of losing their radical edge and getting submerged in the mainstream (personal correspondence, Biel, May 20, 2019).

\subsection{New Assemblages beyond State Compartmentalisation}

With this in mind, it can be argued that there is trajectory towards a naturalisation of the neo-liberal perspective and of its codes when alternatives are mainstreaming. This can be further exemplified with the appearance of displaceable gardens whom by their very essence of privileging mobility over stability, seem to be the symbol of the acceptance of the primacy of property developments over UA projects, or in other words of exchangevalue over use-value.

Nonetheless, London-wide networks are still resisting this recuperation by the mainstream paradigm in many ways. To this end, they are developing original strategies such as:

Expanding skills for empowerment and social inclusion (beyond a leisure activity), valorising all potential resources as community assets (beyond its financial meaning), promoting a food culture to address a systemic 'food poverty' (beyond a deprived sub-population), establishing place-based identities 
for food (beyond organic certification), and creating short food supply chains through social enterprises. (Levidow, 2018, p. 363)

Interestingly, these innovations around food democracy by 'building the asset base and capacity of those involved' can facilitate cross-sectoral activity beyond the siloed mentality associated with top-down governmental programmes (Adams \& Hess, as cited in Levidow, 2018, p. 359) and allow for escaping the State's bureaucratic compartmentalisation. These new assemblages that are sometimes referred to as grassroots social innovations because they carry new forms of participation, democratisation, and networking may have a transformative potential to affect the current institutional logics and the level of citizen's involvement.

Perhaps, this new context since 2008 then allows for the realisation of Hassanein's conception of food democracy, one that goes clearly beyond food democracy as only a rights-based concept, but instead stresses active citizenship (Hassanein, 2003, p. 79). These new forms of interactions belong to the realm of experimental politics, and are ongoing methods requiring gradual, participatory, intelligent action on the part of educated and informed publics (Hassanein, 2003, p. 79). But such methods, in building non-conventional food assemblages and rhizomatic connections, may allow for the articulation of the various political discourses and motivations mentioned earlier, or at the very least offer the arena for debate that could enable a more social vision of food democracy.

\subsection{System-Based Direction or Responsibilisation}

Finally, and to come back to the issue of responsibilisation exposed with the post-2008 trend and with the 'Healthism' discourse, it would be necessary to discuss the links between an active food democracy and the individual as the primary unit of contestation. These links are well explored in Noll's (2014) brilliant work on the relationship between the local food movement and liberalism. On the one hand, she argues that the individual focused food movement is largely compatible with liberalism, as it conceives of citizens/consumers as individuals living out their own conceptions of the good life and thus in accordance with the liberal principle of limited neutrality (Noll, 2014, p. 212). On the other hand, she argues that the systems-based direction is not compatible as it includes within it communitarian critiques of liberalism and brings to the table deeper critiques of the larger structure and our basic relationship with the land, ecosystems, and each other (Noll, 2014, p. 212).

The present direction of London's UA and local food movement seems to be explained by its alignment with neo-liberalism because of its side-lining of the State and more individual focus. Still, responsibilisation is not necessarily negative and Noll concludes that both individual and system-based directions have a place in the larger system and serve different purposes, which forms a dialectic that increases the social and political sustainability of the local food movement as a whole (Noll, 2014). Indeed, while the systems-based direction could be said to be more radical and revolutionary as it aims to change the way people understand and interact with the world, including other people and the environment. The individual focused direction works more pragmatically within the system to cultivate an awareness of the problems of industrial agriculture and to educate people about the benefits of local agri-food systems (Noll, 2014, p. 221). This direction influences people to make better choices and to support local policies that make a local food system possible, but also shapes the demand and brings money into local communities, which enables more ecologically and socially sound agricultural practices of the companies (Noll, 2014, p. 221).

Hence, the individual direction carries with it the logical reasons and the practical experience gained by trying to live this particular lifestyle of an active food citizen and this in turns could lead to greater numbers of people embracing the more revolutionary aspects of the systemsbased direction (Noll, 2014, p. 221). But to come back to Crawford's (1980) point on 'Healthism,' this pragmatist non-political approach will not be enough to address systemic social determinants, and it would not allow for moving beyond the passive and confining roles of consumer, producer or worker (Hassanein, 2003), which will ultimately prove to be ineffective in achieving real active food democracy. Consequently, it can be concluded that for true active food democracy to arise in London there will need to be both individual-focus and systems-based directions to the local food movement, and although there are still some critical voices being heard, the recent direction emphasizing individual responses is to be balanced out by a revival of more radical approaches. This is maybe what we are currently witnessing with movements such as Grow Heathrow or Extinction Rebellion, but it is still too early to conclude anything.

\section{Conclusions}

In summary, this article has demonstrated that UA contributions to food democracy in London happen within the three mutually constitutive realms of political space. First, it was concluded through our examples that institutional channels for food democracy, be it through contestation or collaboration, do exist. However, UA practitioner's involvement remains mostly consultative and do not hold decisive leverage on policy formulation. Secondly, it was observed that there has been a myriad of political discourses articulating this involvement of UA in food democracy, and that since 2008 the neo-liberal discourse has favoured particular channels and practices which may be detrimental to the promotion of UA. Lastly, three practical dilemmas, opportunities and interrogations behind these new channels and discourses were exposed. In short, mainstreaming is necessary to develop 
the local food movement but may impact transformative potential. Moreover, State withdrawal from UA can fragilize the movement but also develop new connections and assemblages. And finally, both the system-based direction and responsibilisation focus for the local food movement can be beneficial if well-balanced.

These conclusions raise further insights for advancing the food democracy debate. Starting with the fact that institutional channels contribute to shaping strategies for food democracy activists, therefore their presence is not necessarily a good sign and the types of participation they entail should be studied, for example, it should be ensured that involvement is not limited to co-optation and that impact on policy formulation is possible. Furthermore, considering the many different motivations behind UA, institutional channels should be decentralised and political practices heterogenous to allow for a more diverse representation of political discourses. The food democracy movement should also be wary of the change in channels and discourses which side-lines the State and privileges public-private partnerships, as neo-liberal rhetoric tends to wrongfully conflate flexibility with resilience. UA practitioners in London should criticise and expose the failures of the 2008 shift to responsibilisation, and lobby for extending allotment's status protections to their community food projects in order to strengthen the local food movement. Finally, advancing food democracy means overcoming the Manichean distinction between pragmatist responsibilisation approaches and system-based critics, ensuring a delicate balance and cooperation between the two sides must be our objective.

Currently in London, but more generally in the Global North, the responsibilisation approach seem to have become predominant and thus a return to a systembased direction becomes necessary as Tilzey (2019) also demonstrated in this issue. Future research on the promotion of such trajectory in this context will be needed. For example, research on the potential of collaborations between London's community groups, social and environmental activists and international advocacy networks to address issues of food justice and food democracy could be very valuable. This could mean assessing the potential for transnational agrarian movements (such as La Vía Campesina and their discourse of food sovereignty) to galvanise UA in the Global North by linking urban citizens' struggles to the Global South peasant movements. Additionally, an inquiry on the necessary legislations needed to enable real active food democracy in the context of London, along with a critical analysis of actor's role and representativeness will also be invaluable to advance the debate. Concretely, this could be interrogating the type of institutional channels needed to realise the principles of active food democracy or food sovereignty, which could potentially be achieved through a comparative analysis of some institutional arrangements worldwide.

\section{Acknowledgments}

The author gratefully acknowledges all the participants to the study, Dr. Robert Biel, Dr. Zeremariam Fre, Professor Adriana Allen, Hannah Sender, Callum Pepper and the reviewers for their constructive comments.

\section{Conflict of Interests}

The author declares no conflict of interests.

\section{References}

Baldy, J., \& Kruse, S. (2019). Food democracy from the top down? State-driven participation processes for local food system transformations towards sustainability. Politics and Governance, 7(4), 68-80.

Bassarab, K., Clark, J., Santo, R., \& Palmer, A. (2019). Finding our way to food democracy: Lessons from US. food policy council governance. Politics and Governance, 7(4), 32-47.

Biel, R., \& Cabannes, Y. (2009). Urban agriculture. DPU News, 51(1), 2-6.

Burchardt, J. (2002). The allotment movement in England, 1793-1873. Rochester: Boydell and Brewer.

Chang, M. (2013). Growing a commons food regime: Theory and practice (Unpublished Doctoral dissertation). University College London, London, UK.

Chang, M., \& Morel, K. (2018). Reconciling economic viability and socio-ecological aspirations in London urban microfarms. Agronomy for Sustainable Development, 38(9), 1-13.

Charmaz, K. (2006). Constructing grounded theory: $A$ practical guide through qualitative analysis. London: SAGE.

Chiffoleau, Y., \& Loconto, A. (2017). Social innovation in agriculture and food: Old wine in new bottles? International Journal of Sociology of Agriculture and Food, 24(3), 306-317.

Coulson, H., \& Sonnino, R. (2019). Re-scaling the politics of food: Place-based urban food governance in the UK. Geoforum, 98(1), 170-179.

Crawford, R. (1980). Healthism and the medicalization of everyday life. International Journal of Health Services, 10(3), 365-388.

Crouch, D., \& Ward, C. (2003). The allotment: Its landscape and culture. Nottingham: Five Leaves Publications.

Edelman, M., Weis, T., Baviskar, A., Borras, J. S. M., HoltGiménez, E., Kandiyoti, D., \& Wolford, W. (2014). Introduction: Critical perspectives on food sovereignty. The Journal of Peasant Studies, 41(6), 911-931.

Edwards, R., \& Phillips, A. (2010, March 11). Creative solutions to 100 -year allotment wait. Islington Now. Retrieved from http://islingtonnow.co.uk/creativesolutions-to-100-year-allotment-wait

Foucault, M. (2002). The archaeology of knowledge. London: Routledge. (Original work published 1969) 
Gibbs, M. (2013, April 16). How 'Dig for Victory' campaign helped win the War. The Telegraph. Retrieved from https://www.telegraph.co.uk/news/ earth/environment/9996180/How-Dig-for-Victorycampaign-helped-win-theWar.html

Greater London Authority. (2006). Healthy and sustainable food for London (The Mayor's food strategy). London: Greater London Authority Publishing. Retrieved from https://www.london.gov.uk/sites/ default/files/the_mayors_food_strategy_2006.pdf

Greater London Authority. (2018a). The London food strategy (Healthy and sustainable food for London). London: Greater London Authority Publishing. Retrieved from https://www.london.gov.uk/sites/ default/files/final_london_food_strategy.pdf

Greater London Authority. (2018b). The London food strategy (Report to the Mayor on consultation on the draft London food strategy). London: Greater London Authority Publishing. Retrieved from https:// www.london.gov.uk/sites/default/files/appendix_ b_-_consultation_report_final_09.01.19.pdf

Greater London Authority. (2018c). The London food strategy (Integrated impact assessment postadoption statement). London: Greater London Authority Publishing. Retrieved from https://www. london.gov.uk/sites/default/files/appendix_c_-_iia_ post_adoption_statement.pdf

Hassanein, N. (2003). Practicing food democracy: A pragmatic politics of transformation. Journal of Rural Studies, 19(1), 77-86.

Holehouse, M., \& Graham, G. (2014, April 17). Allotments being sold off for development despite government pledges. The Telegraph. Retrieved from https://www.telegraph.co.uk/gardening/10774314/ Allotments-being-sold-off-for-developmentdespite-government-pledges.html

Horst, M., McClintock, N., \& Hoey, L. (2017). The intersection of planning, urban agriculture, and food justice: A review of the literature. Journal of the American Planning Association, 83(3), 277-295.

Howkins, A. (2002). From Diggers to Dongas: The land in English radicalism, 1649-2000. History Workshop Journal, 54(1), 1-23.

Just Space. (2018). Just Space governance participation. Just Space. Retrieved from https://justspace.org.uk/ next-londonplan/governance-participation

Just Space. (n.d.). About Just Space. Just Space. Retrieved from https://justspace.org.uk/about

Keller, R. (2011). The sociology of knowledge approach to discourse (SKAD). Human Studies, 34(1), 43-65.

Krippendorff, K. (2004). Content analysis: An introduction to its methodology. Thousand Oaks, CA: SAGE.

Lang, T. (1998). Towards a food democracy. In S. Griffiths \& J. Wallace (Eds.), Consuming passions: Food in the age of anxiety (pp. 13-23). Manchester: Manchester University Press.

Levidow, L. (2018). London's urban agriculture: Building community through social innovation. International
Journal of Sociology of Agriculture and Food, 24(3), 354-376.

London Assembly Environment Committee. (2006). A lot to lose: London's disappearing allotments. London: Greater London Authority Publishing. Retrieved from http://www.spectacle.co.uk/uploads/ other\%20media/allotmentsIndnass.pdf

London Food Link, \& Sustain. (2018). Comments on the draft London Food Strategy. London: Sustain. Retrieved from https://www.sustainweb.org/ resources/files/responses/Summary_LFLResponse_ draftLFS_21June18(1).pdf

McMichael, P. (2008). Peasants make their own history, but not just as they please... Journal of Agrarian Change, 8(2), 205-228.

Monardo, B. (2013). Urban agriculture as a social inclusion vector what potential for innovating urban regeneration strategies? Paper presented at 49th ISOCARP Congress, Brisbane Qld, Australia.

Morgan, K., \& Sonnino, R. (2010). The urban foodscape: World cities and the new food equation. Cambridge Journal of Regions, Economy and Society, 3(2), 209-224.

Neighbourhoods Green. (2014). Edible estates: A good practice guide to food growing for social landlords. London: Sustain. Retrieved from https://www. sustainweb.org/publications/edible_estates

Noll, S. (2014). Liberalism and the two directions of the local food movement. Journal of Agricultural and Environmental Ethics, 27(2), 211-224.

O'Caroll, L. (2018, August 7). UK could run out of food a year from now with no-deal Brexit, NFU warns. The Guardian. Retrieved from https://www. theguardian.com/politics/2018/aug/07/uk-run-outof-food-no-deal-brexit-national-farmers-union

Pimbert, M. (2009). Towards food sovereignty, reclaiming autonomous food systems (Gatekeeper, No. 141). London: IIES. Retrieved from https://pubs.iied.org/ pdfs/14585IIED.pdf

Reclaim the Fields. (n.d.). Where next for the Community Food Movement? Community Food Growers Network. Retrieved from https://www.cfgn.org. uk/2015/08/where-next-now-for-the-communityfood-movement

Renting, H., Schermer, M., \& Rossi, A. (2012). Building food democracy: Exploring civic food networks and newly emerging forms of food citizenship. International Journal of Sociology of Agriculture and Food, 19(1), 289-307.

Richardson, R., \& Ridden, G. (1988). Freedom and the English Revolution: Essays in history and literature. Manchester: Manchester University Press.

Schiavoni, C. (2015). Competing sovereignties, contested processes: Insights from the Venezuelan food sovereignty experiment. Globalizations Journal, 12(4). 466-480.

Sieveking, A. (2019). Food policy councils as loci for practising food democracy? Insights from the case of 
Oldenburg, Germany. Politics and Governance, 7(4), 48-58.

Southgate, J. (2012). Report for trustees allotments and community gardens in Greater London. London: Campaign to Protect Rural England. London Branch. Retrieved from http://www.cprelondon.org.uk/ resources/item/2275-allotments-and-communitygardens-in-greater-london

Strauss, A., \& Juliet, C. (1994). Grounded theory methodology: An overview. In N. Denzin \& Y. Lincoln (Eds.), Handbook of qualitative research (pp. 273-284). Thousand Oaks, CA: SAGE.

Sustain. (2014). Capital Growth: Annual monitoring survey 2013. Sustain. Retrieved from https://www. sustainweb.org/publications/capital_growth_ monitoring_survey_2013/\#

Sustain. (2019a). Strength in diversity Capital Growth survey 2017-18. Sustain. Retrieved from https:// www.sustainweb.org/publications/strength_in_ diversity/?section $=66$

Sustain. (2019b). Influencing policy. Sustain. Retrieved from https://www.sustainweb.org/londonfoodlink/ policy

Tilzey, M. (2019). Food democracy as 'radical' food sovereignty: Agrarian democracy and counterhegemonic resistance to the neo-imperial food regime. Politics and Governance, 7(4), 202-213.

Webster, N., \& Engberg-Pedersen, L. (2002). In the name of the poor: Contesting political space for poverty reduction. London: Zed Books.

Zimmerman, C. (1932). Ernst Engel's law of expenditures for food. The Quarterly Journal of Economics, 47(1), 78-101.

\section{About the Author}

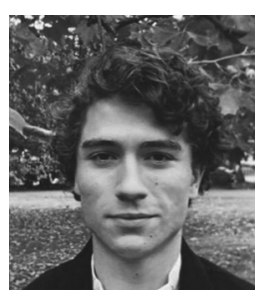

Alban Hasson is a PhD Student at University College London's Bartlett Development Planning Unit. His main research interests lie in urban agriculture, food sovereignty, environmental policy, grassroots innovations and the potential for learning to deliver sustainable urban food systems. His current research focuses on urban agriculture trajectories in the London region and on understanding the practice's various contributions to democracy. 